AC 2011-2921: IMPROVING THE PARTICIPATION AND RETENTION OF MINORITY STUDENTS IN SCIENCE AND ENGINEERING THROUGH SUMMER ENRICHMENT PROGRAMS

Dr. Amelito G. Enriquez, Canada College 


\title{
Improving the Participation and Retention of Minority Students in Science and Engineering Through Summer Enrichment Programs
}

\author{
Amelito Enriquez \\ Cañada College, Redwood City, CA
}

\begin{abstract}
Although many California Community College students enter college with high levels of interest in science and engineering, their levels of preparation for college-level work, especially in math and engineering, are so low that the majority of them drop out or change majors even before taking transfer-level courses. In 2008, Cañada College, a Hispanic-Serving community college in Redwood City, CA, was awarded a Minority Science and Engineering Improvement Program (MSEIP) grant by the US Department of Education to develop and implement a project that aims to maximize the likelihood of success among underrepresented and educationally disadvantaged students interested in pursuing careers in STEM fields. The project, entitled Student On-ramp Leading to Engineering and Sciences (SOLES), incorporates strategies that address challenges and barriers to recruitment, retention and success of minority students. Among the strategies developed for this project are two summer programs that were implemented for the first time in summer 2009. The Summer Math Jam is a two-week intensive mathematics program designed to improve student preparation for college-level math courses. The Summer Engineering Institute is a two-week residential summer camp that offers participating students the opportunity to gain insight into the engineering academic program through a combination of lectures, handson laboratory activities, workshops and projects with engineering professionals. Preliminary results indicate success of both programs. Math Jam participants show improvement in the Math Placement test. Almost all participants scored higher in the placement test compared to their preprogram scores. For sixty four percent of them, the improvement in their scores was high enough to place them to at least the next higher math class. Engineering Institute participants showed improved understanding of the engineering profession and the engineering educational system. Participants from both programs also expressed positive overall attitude and opinions of the program objectives, content, activities and implementation.
\end{abstract}

\section{Introduction}

Community colleges serve as the gateway to higher education for large numbers of students in the U.S., especially minority and low-income students. Yet for many students, the community college gateway does not lead to success. Only one in four students wanting to transfer or earn a degree/certificate did so within six years, according to a recent study of California community colleges ${ }^{1}$. African American and Hispanic students have even lower rates of completion. According to the study, only 15\% of African American students and $18 \%$ of Latino students completed a degree or certificate within six years, compared to $27 \%$ of Caucasian students, and $33 \%$ of Asian students.

For Science, Technology, Engineering, and Math (STEM) fields, lower success and retention rates for minority students are observed at both community college and university levels 
resulting in underrepresentation of minority groups in these professions. For instance, while comprising almost $25 \%$ of the U.S. population, African Americans and Latinos make up less than $7 \%$ of the individuals with B.S. or higher-degrees in the science and engineering fields ${ }^{2}$. Strategies that have been proven effective in increasing the retention and success of minority students in science and engineering include mentoring programs $\mathrm{s}^{3,4}$, introducing context in introductory courses ${ }^{5}$, alternative instructional strategies such as collaborative and interactive learning ${ }^{6}$, summer bridge programs ${ }^{7,8}$, and academic support services such as tutoring, Academic Excellence Workshops (AEWs), and peer mentoring 9

In 2008, Cañada College, a Hispanic-Serving community college in Redwood City, CA, was awarded a Minority Science and Engineering Improvement Program (MSEIP) grant by the US Department of Education. The project, entitled Student On-ramp Leading to Engineering and Sciences (SOLES), aims to maximize the likelihood of success among underrepresented and educationally disadvantaged students interested in pursuing careers in STEM fields by incorporating strategies that address challenges and barriers to recruitment, retention and success of these students. Among the strategies developed for this project are two summer programs that were implemented for the first time in summer 2009. The Summer Math Jam is a two-week intensive mathematics program designed to improve students' preparation for college-level math courses. The Summer Engineering Institute is a two-week residential summer camp that offers participating students the opportunity to gain insight into the engineering academic program through a combination of lectures, hands-on laboratory activities, workshops and projects with engineering professionals. This paper summarizes the results of the first year of implementation of these two summer programs.

\section{The Summer Math Jam}

\subsection{Program Goals}

Although nationally, interest in science and engineering is lower for Latino, African American, and Native American students compared to other ethnic groups ${ }^{2}$, this is not the case at Cañada College.

Table 1 on the next page summarizes the ethnic distribution of students who took the math placement test from April 2006 to May 2008 at Cañada College. Table 2 summarizes the ethnic distribution of students taking the placement test, students declaring an engineering major and students who transferred to a four-year school as an engineering major (2005-2007) for the four largest ethnic groups - Mexican Americans, Caucasian Americans, Asian Americans, and African Americans. Although Mexican Americans represent only 35.5\% of all the students who took the placement test, they represent $50.9 \%$ of students who declared engineering as their major. Despite such a high interest in engineering among Mexican Americans, they represented only $19.0 \%$ of all students who transferred to a four-year school as engineering majors from 2005-2007. These data clearly represent a much lower rate of retention and transfer for both Mexican Americans and African Americans compared to Caucasian Americans and Asian Americans. 
Table 1. Ethnicity distribution of students who took the Math placement test from April 2006 to May 2008.

\begin{tabular}{lcc}
\hline Ethnic Background & No of students & \% of Total \\
\hline African American & 171 & $5.8 \%$ \\
American Indian Alaskan Native & 16 & $0.5 \%$ \\
Asian American & 175 & $5.9 \%$ \\
Caucasian American & 950 & $32.0 \%$ \\
Filipino & 92 & $3.1 \%$ \\
Mexican American & 1055 & $35.5 \%$ \\
Other Hispanic & 135 & $4.5 \%$ \\
Other & 241 & $8.1 \%$ \\
No Response & 135 & $4.5 \%$ \\
Total & 2970 & $100.0 \%$ \\
\hline
\end{tabular}

Table 2. Summary of ethnic distribution of students who took the placement test, who declared STEM majors, who Engineering major and students who transferred to a four-year school as Engineering major (2005-2007) for the four largest ethnic groups.

\begin{tabular}{lccccc}
\hline \multicolumn{1}{c}{$\begin{array}{c}\text { Percentage of } \\
\text { Students Who: }\end{array}$} & $\begin{array}{c}\text { Mexican } \\
\text { Americans }\end{array}$ & $\begin{array}{c}\text { Caucasian } \\
\text { American }\end{array}$ & $\begin{array}{c}\text { Asian } \\
\text { Americans }\end{array}$ & $\begin{array}{c}\text { African } \\
\text { Americans }\end{array}$ & Others \\
\hline $\begin{array}{l}\text { Took the Math } \\
\text { placement Test }\end{array}$ & $35.5 \%$ & $32.0 \%$ & $5.9 \%$ & $5.8 \%$ & $26.6 \%$ \\
$\begin{array}{l}\text { Declared majors in } \\
\text { Engineering }\end{array}$ & $50.9 \%$ & $25.4 \%$ & $3.5 \%$ & $1.6 \%$ & $20.2 \%$ \\
$\begin{array}{l}\text { Transferred as } \\
\text { Engineering majors }\end{array}$ & $19.0 \%$ & $19.0 \%$ & 28.6 & $33.3 \%$ & $33.3 \%$ \\
\hline
\end{tabular}

The inadequate preparation of minority students entering Cañada College is apparent from the results of the math placement tests. Table 3 summarizes the placement test results for students who declared engineering as their major. Mexican American and African American students have the lowest percentages of students placing into Trigonometry, and the highest percentages of students placing into Pre-algebra. The results of these math placement tests have serious and adverse consequences for these students' timely completion of lower-division courses in science and engineering, and subsequent transfer to a university. 
Table 3. Ethnic distribution of Math Placement test results for students who declared majors in Engineering (Data from April 2006-May 2008; 114 students)

\begin{tabular}{lccccc}
\hline Ethnic Group & Pre-algebra & Algebra & $\begin{array}{c}\text { College } \\
\text { Algebra }\end{array}$ & Trig & \% of Total \\
\hline African American & $50.0 \%$ & $0.0 \%$ & $50.0 \%$ & $0.0 \%$ & $5.3 \%$ \\
Asian American & $16.7 \%$ & $0.0 \%$ & $16.7 \%$ & $66.7 \%$ & $5.3 \%$ \\
Caucasian American & $17.2 \%$ & $17.2 \%$ & $48.3 \%$ & $17.2 \%$ & $25.4 \%$ \\
Mexican American & $31.0 \%$ & $24.1 \%$ & $34.5 \%$ & $10.3 \%$ & $50.9 \%$ \\
Other Hispanic & $16.7 \%$ & $0.0 \%$ & $33.3 \%$ & $50.0 \%$ & $5.3 \%$ \\
Other & $33.3 \%$ & $66.7 \%$ & $0.0 \%$ & $0.0 \%$ & $2.6 \%$ \\
No Response & $0.0 \%$ & $33.3 \%$ & $0.0 \%$ & $66.7 \%$ & $5.3 \%$ \\
\% of Total & $25.4 \%$ & $20.2 \%$ & $35.1 \%$ & $19.3 \%$ & $100.0 \%$ \\
\hline
\end{tabular}

Engineering majors require two years of courses that include sequences of courses in calculus and physics. A student who starts at College Algebra has an additional one and a half years of mathematics (College Algebra, Trigonometry and Pre-calculus) on top of the two-year sequence of lower-division transferable courses. A student who starts at Pre-algebra has an additional two and a half years (Pre-algebra, Algebra, College Algebra, Trigonometry and Pre-calculus) of mathematics before they are ready to take Calculus. Hence, for Mexican American students at Cañada who want to major in engineering, $34.5 \%$ of them would need at least three and a half years, $24.1 \%$ would need at least four years, and $31 \%$ of them would need at least four and a half years in a community college before they can even transfer to a four-year university. Half of the African American students will need at least three years, while the other half would need at least four years at a community college before transferring. For many of them with family obligations and no family support, this is simply too long of a career path.

The Summer Math Jam at Cañada College was developed to help these students who have expressed interest in pursuing engineering and other STEM majors but placed low in the sequence of math courses.

The Summer 2009 Math Jam was developed with the following program goals:

1. Help students progress faster through Cañada's math sequence to enable them to transfer to a 4 year university earlier or to complete an associate's degree earlier.

2. Recruit as many students as possible into STEM majors.

3. Increase students' awareness of the tools, skills, and resources they need to be successful college students.

4. Develop a community of learners among program participants.

Appendix A shows a summary of the two-week schedule of the program that was run from June 8 to June 19, 2009. This two-week period was selected to coincide with Cañada College's break between the end of spring 2009 semester and the beginning of the summer 2009 session. 
Morning sessions were mostly devoted to studying math either in groups or individually using MyMathTest $^{10}$, an online system developed by Pearson Education for developing math placement tests and short math refresher programs. Note that the first week of the program had more workshops related to resources and skills needed for college success. Many of the workshops planned for the second week were either cancelled or made optional as a result of a mid-program focus group that indicated that students wanted to devote more time to studying math, and less on these workshops.

\subsection{Profile of 2009 Summer Math Jam Students}

The 2009 Summer Math Jam recruited 40 participants, with 34 of them successfully completing the program. Table 4 is a summary of the demographics of the 2009 Summer Math Jam 34 participants who completed the program. The gender distribution of $64.7 \%$ female and $35.3 \%$ male is very similar to the College's overall gender distribution (63\% female, $34 \%$ male, and $3 \%$ unknown). The biggest ethnic group is Hispanic representing $61.8 \%$ of Math Jam students, significantly higher than the College's overall Hispanic student body of $44 \%$. Fifty percent of the students are first in their family to attend college.

Table 4. Demographics of 2009 Math Jam participants.

\begin{tabular}{lrr}
\hline Demographics & $\mathbf{N}$ & $\%$ \\
\hline Gender & & \\
$\quad$ Female & 22 & $64.7 \%$ \\
Male & 12 & $35.3 \%$ \\
$\quad$ Total & 34 & \\
Ethnicity & & \\
$\quad$ Afro-American & 2 & $5.9 \%$ \\
Asian & 1 & $2.9 \%$ \\
Caucasian & 7 & $20.6 \%$ \\
Hispanic & 21 & $61.8 \%$ \\
Other & 3 & $8.8 \%$ \\
Total & 34 & \\
First in Family to Attend College? & \\
Yes & 17 & $50.0 \%$ \\
No & 17 & $50.0 \%$ \\
Total & 34 & \\
\hline
\end{tabular}

\subsection{Math Jam Results}

To evaluate the success of Math Jam in achieving its primary goal of helping students progress more quickly through the sequence of math courses they need before transfer, the Math Test Placement scores of the participants before and after Math Jam are compared. Table 5 summarizes this comparison. Of the 33 students who had pre- and post-Math Jam test scores, 31 (or 93.9\%) scored higher after completing Math Jam, one student scored lower, and one 
student's score did not change. Twenty one out of 33 students (or 63.6\%) improved their scores enough to be placed into a higher math course compared to their pre-Math Jam results. These results although not as dramatic as what the program staff was aiming for are slightly better than the 56\% "jump rate" for participants of a similar two-week summer program at Pasadena City College ${ }^{11}$.

Table 5. Test Placement Results after Math Jam.

\begin{tabular}{lrc}
\hline $\begin{array}{l}\text { Results of Post Math Jam } \\
\text { Placement Test }\end{array}$ & N & \% \\
\hline Better & 31 & $93.9 \%$ \\
Unchanged & 1 & $3.0 \%$ \\
Worse & 1 & $3.0 \%$ \\
Placed to a Higher Level & 21 & $63.6 \%$ \\
\hline
\end{tabular}

Table 6. Math Jam Student Survey Attitudes.

\begin{tabular}{|c|c|c|c|}
\hline $\begin{array}{l}\text { Attitudes } \\
\text { Response Scale: } 5 \text { - Strongly Agree, } 4 \text { - Agree, } \\
3 \text { - Neutral, } 2 \text { - Disagree, } 1 \text { - Strongly Disagree. }\end{array}$ & $\begin{array}{c}\text { Pre- } \\
\text { Program }\end{array}$ & $\begin{array}{c}\text { Post- } \\
\text { Program }\end{array}$ & $\begin{array}{r}\text { Difference } \\
\text { (Post - Pre) }\end{array}$ \\
\hline I feel (was) excited about participating in Math Jam. & 4.12 & 4.15 & 0.03 \\
\hline I feel anxious about studying math. & 3.65 & 3.48 & -0.17 \\
\hline I have effective math study skills. & 2.91 & 3.48 & $0.57^{*}$ \\
\hline $\begin{array}{l}\text { I am confident that I have the necessary skills and } \\
\text { academic preparation to be a successful college } \\
\text { student. }\end{array}$ & 3.79 & 4.04 & $0.24^{*}$ \\
\hline $\begin{array}{l}\text { I am confident that Canada College is the right } \\
\text { college for me. }\end{array}$ & 4.44 & 4.58 & 0.14 \\
\hline $\begin{array}{l}\text { I am confident that I have selected an appropriate } \\
\text { major. }\end{array}$ & 4.21 & 3.96 & -0.24 \\
\hline $\begin{array}{l}\text { I felt connected to students, tutors, teachers and staff } \\
\text { in Math Jam. }\end{array}$ & - & 4.31 & - \\
\hline It was helpful for me to participate in Math Jam. & - & 4.52 & - \\
\hline
\end{tabular}

* The difference is statistically significant $(p<0.050)$.

Table 6 summarizes the result of the pre- and post-program student survey designed to evaluate the success of Math Jam in achieving its secondary goals of increasing student awareness of tools, skills and resources needed to succeed in college. The survey evaluated student attitudes 
towards the program, their selected major, and Cañada College as their selected school, as well as their perceptions of their level of preparation for college-level work before and after Math Jam. Results of the survey show that Math Jam maintained student enthusiasm for the program, reduced (slightly although not statistically significant) math anxiety, improved student math study skills (statistically significant), and academic preparation for college success. The program was not successful in helping students select an appropriate major as indicated by a slight drop in the students' level of confidence regarding their selected major. The program was successful in building a sense of community among the participants and staff.

Table 7 summarizes the results of survey of students' opinion of their knowledge and skills needed for college success. Statistically significant improvements in awareness of education planning, math anxiety, learning styles, financial aid and scholarships, and the MyMathTest software were achieved. The most significant gain is on the use of MyMathTest software, and this is no surprise considering that the focus of the program is on studying math using this tool. The measured increase in student awareness of the transfer process and exploring majors, time management, students' personal strengths, and the use of calculators for a math class were not statistically significant. There is a slight decrease (although not statistically significant) in student perceived knowledge of essay writing. It should be noted that due to student demand for more time spent on studying math, the Math Jam staff decided to cancel some workshops, and make others optional.

Table 7. Math Jam Student Survey: knowledge and skills important for college success.

\begin{tabular}{lccc}
\hline $\begin{array}{l}\text { Knowledge and Skills for College Success } \\
\text { Response Scale: 4 - A Lot, 3 - Quite a Bit, }\end{array}$ & $\begin{array}{c}\text { Pre- } \\
\text { Program }\end{array}$ & $\begin{array}{c}\text { Post- } \\
\text { Program }\end{array}$ & $\begin{array}{c}\text { Difference } \\
\text { (Post - Pre) }\end{array}$ \\
\hline Time management & 3.24 & 3.52 & 0.28 \\
Education planning & 3.18 & 4.07 & $0.89^{* *}$ \\
Math anxiety & 3.09 & 3.70 & $0.62^{*}$ \\
Your learning style & 3.41 & 3.96 & $0.55^{*}$ \\
Your personal strengths & 3.62 & 3.74 & 0.12 \\
Financial aid and scholarships & 2.76 & 3.78 & $1.01^{* *}$ \\
Essay writing & 3.18 & 2.85 & -0.32 \\
How to transfer and explore majors & 2.84 & 3.30 & 0.46 \\
How to use a calculator for a math class & 3.18 & 3.22 & 0.04 \\
MyMathTest Software & 2.50 & 4.30 & $1.80^{* *}$ \\
\hline
\end{tabular}

* The difference is statistically significant $(p<0.050)$.

** The difference is statistically significant $(p<0.001)$.

On the areas of college resources and support services, statistically significant gains were measured in student awareness of the Learning Center, Tutorial Services, Financial Aid Office, Transfer Center, TRIO and MESA as shown in Table 8. The measured gains in student 
awareness of the Library, Health Center, Psychological Services, Disabled Student Services, and EOPS were not statistically significant due to the need to have workshops related to these areas either be canceled or made optional in order to allot more math study time.

Table 8. Math Jam Student Survey: Knowledge of College Resources and Support Services.

\begin{tabular}{lccc}
\hline $\begin{array}{l}\text { Knowledge of Resources and Support Services } \\
\text { Response Scale: 4 - A Lot, 3 - Quite a Bit, }\end{array}$ & $\begin{array}{c}\text { Pre- } \\
\text { Program }\end{array}$ & $\begin{array}{c}\text { Post- } \\
\text { Program }\end{array}$ & $\begin{array}{c}\text { Difference } \\
\text { (Post - Pre) }\end{array}$ \\
\hline Library & 2.94 & 3.52 & 0.58 \\
Learning Center & 3.21 & 4.48 & $1.27^{* *}$ \\
Health Center & 1.97 & 2.15 & 0.18 \\
Psychological Services & 1.73 & 2.08 & 0.35 \\
Tutorial Services & 2.79 & 4.19 & $1.40^{* *}$ \\
Financial Aid Office & 2.82 & 3.96 & $1.14^{* *}$ \\
Transfer Center & 2.06 & 2.70 & $0.64^{*}$ \\
Disabled Student Services & 1.41 & 1.81 & 0.41 \\
TRIO & 2.30 & 3.07 & $0.77^{*}$ \\
EOPS & 2.64 & 3.22 & 0.59 \\
MESA & 2.21 & 4.07 & $1.86^{* *}$ \\
\hline
\end{tabular}

* The difference is statistically significant $(p<0.050)$.

** The difference is statistically significant $(p<0.001)$.

As a whole, the 2009 Math Jam was successful in achieving most of its goals except those related to recruiting more students into the STEM fields, or helping them select an appropriate major.

3. The Summer Engineering Institute

The Summer Engineering Institute (SEI) is a two-week residential program held on campus at San Francisco State University. The goals of the program are to introduce students to the engineering educational system and the engineering profession, to recruit students into an engineering field, increase student awareness of resources and skills needed for college success, and to increase student knowledge of specific engineering topics. Appendices B-1 and B-2 show a summary of the schedule of the 2009 Summer Engineering Institute that was held from July $19^{\text {th }}$ to July $31^{\text {st }}$. Mornings were generally devoted to lecture sessions, with group activities and hands-on workshops in the afternoon to reinforce concepts learned from the lectures. Most evenings were devoted to working on group projects.

3.1 Profile of SEI Students 
Due to budgetary constraints, the implementation of the 2009 Summer Engineering Institute was done in partnership with the California Department of Transportation (Caltrans). There were 54 participants; 25 were jointly recruited by Cañada College and San Francisco State University, and 29 were recruited by Caltrans. For the purpose of this paper, only the 25 students recruited by Cañada and SFSU are included in the analysis.

Table 9 is a summary of the demographics of the 25 participants that were recruited by Cañada College and San Francisco State. Thirteen of the students were female, and twelve were male. Hispanics constitute the largest ethnic group at $48 \%$, followed by Asians or Pacific Islanders (24\%), and African Americans (12\%). Forty-four percent were the first in their family to attend college.

Table 9. Demographics of 2009 Summer Engineering Institute.

\begin{tabular}{lrr}
\hline Demographics & N & \% \\
\hline Gender & 13 & $52.0 \%$ \\
$\quad$ Female & 12 & $48.0 \%$ \\
Male & 25 & \\
Total & & \\
Ethnicity & 3 & $12.0 \%$ \\
$\quad$ African American & 6 & $24.0 \%$ \\
Asian American or Pacific Islander & 2 & $8.0 \%$ \\
Caucasian & 12 & $48.0 \%$ \\
Hispanic & 2 & $8.0 \%$ \\
Other & 25 & \\
Total & & \\
First in Family to Attend College? & 11 & \\
$\quad$ Yes & 14 & $56.0 \%$ \\
No & 34 & \\
Total & & \\
\hline
\end{tabular}

To evaluate the success of SEI in achieving its goal of recruiting students to major in an engineering field, a pre- and post-survey of students' intended major in college was done. Table 10 on the next page summarizes the results of this survey. At the beginning of the program, 17 out of the 25 students (or 68\%) indicated one of the fields of engineering as their intended major, with Engineering (General) as the most popular choice. The remaining 8 out of the 25 students (or 32\%) were undecided. After the program, students intended major remained the same except for one student who switched from Civil Engineering to Landscape Architecture. Students who were initially undecided remained undecided. Clearly, the program failed to recruit additional students to major in any of the engineering fields. Table 10. SEI Student Survey: Intended Major in College. 


\begin{tabular}{lcccc}
\hline \multirow{2}{*}{ Major } & \multicolumn{2}{c}{ Pre-SEI } & \multicolumn{2}{c}{ Post-SEI } \\
& N & \% & N & $\%$ \\
\hline Biomedical engineering & 1 & $4.0 \%$ & 1 & $4.0 \%$ \\
Civil Engineering & 4 & $16.0 \%$ & 3 & $12.0 \%$ \\
Computer engineering & 2 & $8.0 \%$ & 2 & $8.0 \%$ \\
Electrical Engineering & 0 & $0.0 \%$ & 0 & $0.0 \%$ \\
Engineering (General) & 7 & $28.0 \%$ & 7 & $28.0 \%$ \\
Mechanical & 3 & $12.0 \%$ & 3 & $12.0 \%$ \\
Undecided & 8 & $32.0 \%$ & 8 & $32.0 \%$ \\
Other (Landscape Architecture) & 0 & $0.0 \%$ & 1 & $4.0 \%$ \\
Total & 25 & & 25 & \\
\hline
\end{tabular}

The failure of the SEI program to achieve its primary goal of recruiting students into engineering is also reflected in Table 11. Although student enthusiasm for the program increased significantly, there was a statistically significant decrease in student confidence that the Institute will help them select an appropriate engineering major. The slight increase in student level of confidence that they have the necessary skills and preparation for college success is not statistically significant.

Table 11. SEI Student Survey: Attitudes.

\section{Attitudes}

Response Scale: 5 - Strongly Agree, 4 - Agree, 3 - Neutral, 2 - Disagree, 1 - Strongly Disagree.

\section{Pre- Post- Difference Program Program (Post - Pre)}

I feel excited about participating in Summer Engineering Institute.

$$
4.58
$$

I am confident that I have the skills and academic preparation to be a successful college student.

0.10

I am confident that SEI will help me in selecting an appropriate Engineering major. 4.16 3.63 $-0.54 *$

* The difference is statistically significant $(p<0.050)$.

With regards to SEI's goal of increasing students' awareness of knowledge and skills that are important for college success, the results of pre- and post-SEI student surveys are summarized in Table 12. All the gains that were measured after the program were statistically significant except in the area of using a calculator for engineering calculations. Pre- and post-SEI average student responses were all between "Quite a Bit" and "A Lot" in all areas except for "How to transfer and explore majors." This is again an indication that the program was not successful in helping students explore career options, or select an appropriate major. 
Table 12. SEI Student Survey: Knowledge and Skills important for College Success.

\begin{tabular}{lccc}
\hline $\begin{array}{l}\text { Knowledge and Skills for College Success } \\
\text { Response Scale: 4 - A Lot, 3 - Quite a Bit, }\end{array}$ & $\begin{array}{c}\text { Pre- } \\
\text { Program }\end{array}$ & $\begin{array}{c}\text { Post- } \\
\text { Program }\end{array}$ & $\begin{array}{c}\text { Difference } \\
\text { (Post - Pre) }\end{array}$ \\
\hline Time management & 3.72 & 3.96 & 0.24 \\
Education planning & 3.80 & 3.83 & 0.03 \\
Your learning style & 3.60 & 3.83 & 0.23 \\
Your personal strengths & 3.76 & 4.00 & 0.24 \\
Self Confidence & 3.92 & 4.13 & 0.21 \\
Essay writing & 3.36 & 3.38 & 0.02 \\
How to transfer and explore majors & 2.80 & 2.92 & 0.12 \\
Using a calculator for Engineering Calculations & 3.04 & 3.67 & $0.63 *$ \\
\hline
\end{tabular}

* The difference is statistically significant $(p<0.050)$.

With regards to its goal of increasing student knowledge of college resources and support services, results of the student surveys are shown in Table 13. There is no statistically significant change in student responses in any of the areas after the completion of SEI.

Table 13. SEI Student Survey: Knowledge of College Resources and Support Services.

\begin{tabular}{lccc}
\hline $\begin{array}{l}\text { Knowledge of Resources and Support Services } \\
\text { Response Scale: 4 - A Lot, 3 - Quite a Bit, }\end{array}$ & $\begin{array}{c}\text { Pre- } \\
\text { Program }\end{array}$ & $\begin{array}{c}\text { Post- } \\
\text { Program }\end{array}$ & $\begin{array}{c}\text { Difference } \\
\text { (Post - Pre) }\end{array}$ \\
\hline - Some, 1 - A little, 0 - Nothing. & 3.16 & 3.50 & 0.34 \\
Library & 2.56 & 2.67 & 0.11 \\
Undergraduate Advising & 2.88 & 3.17 & 0.29 \\
Learning center & 2.60 & 2.71 & 0.11 \\
Health center & 2.20 & 2.29 & 0.09 \\
Psychological services & 2.88 & 2.96 & 0.08 \\
Tutorial services & 3.04 & 2.75 & -0.29 \\
Financial aid office & 2.32 & 2.38 & 0.06 \\
Transfer center & 1.88 & 1.96 & 0.08 \\
Disabled student services & 2.96 & 3.08 & 0.12 \\
MESA & & & \\
\hline
\end{tabular}

Table 14. SEI Student Survey: Knowledge of Specific Engineering Topics. 


\begin{tabular}{lccc}
\hline $\begin{array}{l}\text { Knowledge of Specific Engineering Topics } \\
\text { Response Scale: 4 - A Lot, 3-Quite a Bit, }\end{array}$ & $\begin{array}{c}\text { Pre- } \\
\text { Program }\end{array}$ & $\begin{array}{c}\text { Post- } \\
\text { Program }\end{array}$ & $\begin{array}{c}\text { Difference } \\
\text { (Post - Pre) }\end{array}$ \\
\hline - Some, 1 - A little, 0 - Nothing. & 2.28 & 2.46 & 0.18 \\
Computer-Aided Design (CAD) & 2.16 & 2.67 & $0.51^{*}$ \\
Raboratory Experimental Procedures & 2.04 & 2.79 & $0.75^{*}$ \\
Computer Engineering & 2.04 & 2.92 & $0.88^{* *}$ \\
Electronics and Electrical Engineering & 2.40 & 3.29 & $0.89^{* *}$ \\
Geotechnical Engineering & 1.72 & 2.83 & $1.11^{* * *}$ \\
Hydraulics & 1.76 & 2.88 & $1.12^{* * *}$ \\
Data Analysis & 2.24 & 3.38 & $1.14^{* * *}$ \\
Operations Analysis & 2.04 & 3.21 & $1.17^{* * *}$ \\
Bridge Design & 2.16 & 3.38 & $1.22^{* * *}$ \\
Engineering Design Process & 2.20 & 3.79 & $1.59^{* * *}$ \\
Surveying and Map Reading & 2.20 & 3.88 & $1.68^{* * *}$ \\
\hline
\end{tabular}

* The difference is statistically significant $(p<0.050)$.

$* *$ The difference is statistically significant $(p<0.010)$.

$* * *$ The difference is statistically significant $(p<0.001)$.

The 2009 SEI's main area of success is in increasing student knowledge of specific engineering topics. Table 14 shows that except for Computer-Aided Design (CAD), statistically significant increase in student knowledge of engineering topics covered in the Institute. It should be noted that the 2009 SEI was planned and implemented through collaboration with the California Department of Transportation (Caltrans). As a result, the most significant increases in student knowledge were in subject areas that directly pertain to the expertise of the Caltrans personnel who served as lecturers and project advisors for the participating students.

Although SEI was successful in increasing student knowledge and understanding of specific engineering topics and of the engineering profession, it did not achieve its goal of recruiting additional students to major in engineering. Results of pre- and post-program surveys asking students to rate their confidence that "the Summer Engineering Institute will help in selecting an appropriate Engineering major" show that student confidence level dropped significantly after the program. One possible contributing factor could be the overemphasis given to Civil Engineering and other related fields brought about by the partnership with Caltrans whose personnel have expertise mostly in these fields. However, an investigation on research and literature on career selection, especially those in the STEM fields, indicates that the underlying reason might be beyond the SEI curriculum.

Many researchers believe that career interests and career plans start developing in middle schools, and recommend that career explorations and career planning begin before high school, when students have already made major career decisions in the form of curriculum 
choices $^{12,13,14,15,16,17,18}$. Many of these middle school and high school students passively eliminate technical career options by not choosing courses that are not needed for these STEM fields ${ }^{12}$. In many cases, students who pursue STEM courses have made these career decisions before they finish high school so that STEM career exploration summer programs before their senior year, or before they start college may be too late.

\section{Conclusion}

The first year of implementation of the two MSEIP summer programs at Cañada College shows success in achieving some of the programs' goals. Math Jam was successful in achieving its primary goal of helping students progress faster through Cañada's math sequence, with $63.6 \%$ of student participants placing to at least the next higher math course. It was also successful in increasing students' awareness of college success tools and skills, and in creating a community of learners that felt comfortable at Cañada. Over the next few semesters, the academic performance of Math Jam participants will be monitored to determine whether the success of the program results in subsequent student academic success. For future implementations of Math Jam, even more emphasis will be given to studying math, and less on college success workshops. Workshops will only focus on topics that are more directly related to math, such as overcoming math anxiety and test taking strategies. Additional workshops on other college success skills and resources will be made available to math jam participants through the College's Learning Resource Center during the academic year.

The Summer Engineering Institute was successful in increasing student knowledge and understanding of specific engineering topics and of the engineering profession. It was also successful in maintaining and even increasing participant excitement about the program. However, increased knowledge of the profession and increased excitement about the summer institute did not necessarily translate to increased interest among participants to pursue engineering as a career. Among students who solidified their choice of an engineering career and decided to major in one of the engineering fields, the program has provided context to their study of engineering - a strategy that has been proven to increase student motivation and persistence ${ }^{5}$ - especially as they struggle through the first two years of the engineering curriculum. For future implementations of the Summer Engineering Institute, a more balanced curriculum will be adopted to introduce students to the different fields of engineering through a combination of lectures, laboratory activities, workshops, and design projects. And unlike the previous SEI where all participants worked on the same culminating design project, participants will be given the option to select a project that most closely fits their interests. To better understand the effect of this new curriculum on student career choices, additional assessment plans will be developed, including focus groups and exit interviews of student participants, and follow up studies of both groups of students - those who pursue an engineering major and those who chose to major in a non-engineering field. Finally, the SEI project team will consider developing a curriculum for a summer engineering institute suitable for middle school students to introduce them to the engineering profession before they make major decisions regarding their future careers.

\section{Acknowledgements}


This project was supported by a grant from the US Department of Education through the Minority Science and Engineering Improvement Program (MSEIP, Award No. P120A080080). The author would also like to thank Felicia Tripp of Cañada College for her assistance in gathering and analyzing the data for Math Jam, Vish Ganthi of San Francisco State University for his assistance in gathering data for the Summer Engineering Institute, and Dr. Nilgun Ozer for her role in planning and implementing the Summer Engineering Institute.

\section{Bibliography}

1. Shulock, N., \& Moore, C. (2007). Rules of the game: How state policy creates barriers to degree completion and impedes student success in the California Community College. Sacramento: Institute for Higher Education Leadership and Policy.

2. National Science Foundation (2007). Women, minorities, and persons with disabilities in science and engineering: 2007, Arlington, VA: National Science Foundation, Division of Science Resource Statistics.

3. National Science Foundation (2004). Women, minorities, and persons with disabilities in science and engineering: 2004, Arlington, VA: National Science Foundation, Division of Science Resource Statistics.

4. Goodman Research Group (2002). Final report of the women's experiences in college engineering (WECE) project, Cambridge, MA.

5. Davis, C-S. \& Finelli, C.J. (2007), Diversity and Retention in Engineering, New Directions for Teaching and Learning, v2007, n111, p63-7.

6. Derlin, R.L. \& McShannon, J.L. (2000), Faculty and Student Interaction and Learning Styles of Engineering Undergraduates, Retrieved May 10, 2008 from http://www.eric.ed.gov/ERICDocs/data/ericdocs2sql/content_storage_01/0000019b/80/16/89/1d.pdf.

7. Goldberg, J. \& Sedlacek, W. (1996), Summer Study in Engineering for High School Women, Maryland University, College Park, Maryland.

8. Pantano, J. (1994), Comprehensive Minority SEM Programs at Santa Fe Community College, Paper presented at the Annual International Conference of the National Institute of Staff and Organizational Development on Teaching Excellence and Conference of Administrators, Austin, TX, May 22-25, 1994.

9. Kane, M., Beals, C., Valeau, E. \& Johnson, M. (2004), Fostering Success among Traditionally Underrepresented Student Groups: Hartnell College's Approach to Implementation of the Math, Engineering, and Science Achievement (Mesa) Program, Community College Journal of Research and Practice Journal Citation: v28 n1 p17-26 Jan 2004.

10. Pearson Education (2008). MyMathTest. Pearson Education. Retrieved January 7, 2010 from http://mymathtest.com/login_mmt.htm.

11. Pasadena City College (n.d.), Summer Math Jam: Preparing Students for Success, Retrieved October 9, 2009 from http://www.achievingthedream.org/_pdfs/_strategyinstitute07/PreparingStudentsforSuccess.pdf

12. Akos, P., Lambie, G. W., Milsom,A., \& Gilbert, K. (2007), Early Adolescents' Aspirations and Academic Tracking: An Exploratory Investigation, Professional School Counseling, v11 n1, p57-64.

13. ACT. (2008). The Economic Benefits of Academic and Career Explorations, Iowa City, IA. Retrived October 11, 2009 from http://www.act.org/research/policymakers/pdf/EconomicBenefits.pdf

14. Marcos, K. (2003). Gearing-Up for Career Awareness: Profile of a Middle School Career Program, ERIC/CASS Digest, Retrieved October 11, 2009 from http://www.ericdigests.org/2003-5/career.htm.

15. Castellano, M., Stringfield, S., \& Stone, J.R., III. (2002). Helping disadvantaged youth succeed in school: Second year findings from a longitudinal study of CTE-based whole-school reforms. Columbus OH: National Dissemination Center for Career and Technical Education. Retrieved October 12, 2009 from http://www.eric.ed.gov/ERICDocs/data/ericdocs2sql/content_storage 01/0000019b/80/1a/a4/43.pdf. 
16. Foud, N.A. (1995). Career linking: An intervention to promote math and science career awareness. Journal of Counseling and Development, 73. Alexandria, VA: American Counseling Association, v73 n5 p527-34.

17. O’Brien, K.M., Dukstein, R.D., Jackson, S.L., Tomlinson, M.J. \& Kamatuka, N.A. (1999). Broadening career horizons for students in at-risk environments. The Career Development Quarterly, 47. Alexandria, VA: National Career Development Association. Retrieved October 12, 2009 from http://www.ade.az.gov/cte/CTEDeliverySystem/RationaleCareerExploration10-11-05.pdf.

18. Toepfer, C.F., Jr. (1997). Middle Level School Concerns and Rural School-To-Employment Issues: In Search of Better Ways, Journal of Research in Rural Education, 13 (1), 28-36. Retrieved October 12. 2009 from http://jrre.psu.edu/articles/v13,n1,p28-36,Toepfer.pdf. 


\section{Appendix A \\ 2009 Math Jam Schedule}

Week 1

\begin{tabular}{|c|c|c|c|c|c|}
\hline & June 8 & June 9 & June 10 & June 11 & June 12 \\
\hline Time & Monday & Tuesday & Wednesday & Thursday & Friday \\
\hline $9-10 \mathrm{am}$ & $\begin{array}{l}\text { Welcome \& Ice } \\
\text { Breaker }\end{array}$ & $\begin{array}{l}\text { Math Study } \\
\text { Skills }\end{array}$ & \multirow{2}{*}{ Math! } & \multirow{2}{*}{ Math! } & \\
\hline $10-12 \mathrm{pm}$ & $\begin{array}{l}\text { Placement Test / } \\
\text { Review Results }\end{array}$ & Math! & & & \\
\hline $12-12: 30 \mathrm{pm}$ & Lunch & Lunch & Lunch & \multirow{3}{*}{$\begin{array}{l}\text { Lunch \& Mesa } \\
\text { Panel }\end{array}$} & Lunch \\
\hline $12: 30-1 \mathrm{pm}$ & $\begin{array}{l}\text { Meet the staff \& } \\
\text { Overview of } \\
\text { Math Jam }\end{array}$ & \multirow[t]{2}{*}{$\begin{array}{l}\text { Math Anxiety } \\
\text { Assessment }\end{array}$} & \multirow[t]{2}{*}{ Financial Aid } & & \multirow{5}{*}{ Field Trip } \\
\hline $1-1: 30 \mathrm{pm}$ & \multirow{2}{*}{$\begin{array}{l}\text { Time } \\
\text { Management }\end{array}$} & & & & \\
\hline $1: 30-2 \mathrm{pm}$ & & \multirow{3}{*}{$\begin{array}{l}\text { Ed Plan } \\
\text { Counseling OR } \\
\text { Math Anxiety } \\
\text { Workshop }\end{array}$} & \multirow{3}{*}{$\begin{array}{l}\text { Ed Plan } \\
\text { Counseling OR } \\
\text { Time } \\
\text { Management }\end{array}$} & \multirow{3}{*}{ Learning Styles } & \\
\hline $2-2: 20 \mathrm{pm}$ & $\begin{array}{l}\text { Why an } \\
\text { Education Plan? }\end{array}$ & & & & \\
\hline $\begin{array}{l}2: 20-2: 30 \\
\mathrm{pm}\end{array}$ & $\begin{array}{l}\text { Signups for } \\
\text { Work Sessions }\end{array}$ & & & & \\
\hline $\begin{array}{l}2: 30-3: 30 \\
\text { pm } \\
\text { [Optional }]\end{array}$ & & $\begin{array}{l}\text { Individual Ed } \\
\text { Plan Counseling } \\
\text { Skills Counseling }\end{array}$ & $\begin{array}{l}\text { Individual Ed } \\
\text { Plan Counseling } \\
\text { Skills Counseling }\end{array}$ & $\begin{array}{l}\text { Individual Ed } \\
\text { Plan Counseling } \\
\text { Skills Counseling }\end{array}$ & \\
\hline
\end{tabular}

\section{Week 2}

\begin{tabular}{|c|c|c|c|c|c|}
\hline & June 15 & June 16 & \begin{tabular}{|l|} 
June 17 \\
\end{tabular} & June 18 & June 19 \\
\hline Time & Monday & Tuesday & Wednesday & Thursday & Friday \\
\hline $9-10 \mathrm{am}$ & \multirow[t]{2}{*}{ Math! } & \multirow[t]{2}{*}{ Math! } & \multirow[t]{2}{*}{ Math! } & $\begin{array}{l}\text { Post-Program } \\
\text { Survey }\end{array}$ & \\
\hline $10-12 \mathrm{pm}$ & & & & Placement Test & \\
\hline $12-12: 30 \mathrm{pm}$ & Lunch & Lunch & Lunch & \multirow{3}{*}{$\begin{array}{l}\text { Lunch \& Guest } \\
\text { Speaker }\end{array}$} & \multirow{5}{*}{$\begin{array}{l}\text { Barbecue } \\
\text { and } \\
\text { Closing } \\
\text { Ceremony }\end{array}$} \\
\hline 12:30-1 pm & \multirow{3}{*}{$\begin{array}{l}\text { LEAP } \\
\text { Strengths Quest }\end{array}$} & \multirow{4}{*}{ Math! } & \multirow{4}{*}{ Math! } & & \\
\hline $1-1: 30 \mathrm{pm}$ & & & & & \\
\hline $1: 30-2 \mathrm{pm}$ & & & & Transfer OR & \\
\hline $2-2: 30 \mathrm{pm}$ & $\begin{array}{l}\text { Math Jam and } \\
\text { You }\end{array}$ & & & $\begin{array}{l}\text { Graphing Calc } \\
\text { Workshop }\end{array}$ & \\
\hline $\begin{array}{l}2: 30-3: 30 \\
\mathrm{pm} \\
\text { [Optional] }\end{array}$ & $\begin{array}{l}\text { Individual Ed } \\
\text { Plan Counseling } \\
\text { / Skills } \\
\text { Counseling }\end{array}$ & $\begin{array}{l}\text { Individual Ed } \\
\text { Plan Counseling } \\
\text { / Skills } \\
\text { Counseling }\end{array}$ & $\begin{array}{l}\text { Individual Ed } \\
\text { Plan Counseling } \\
\text { / Skills } \\
\text { Counseling }\end{array}$ & $\begin{array}{l}\text { Individual Ed } \\
\text { Plan Counseling } \\
\text { / Skills } \\
\text { Counseling }\end{array}$ & \\
\hline
\end{tabular}


Appendix B-1

2009 Summer Engineering Institute Schedule: Week 1

\begin{tabular}{|c|c|c|c|c|c|c|c|}
\hline & July 19 & July 20 & July 21 & July 22 & July 23 & July 24 & July 25 \\
\hline Time & Sunday & Monday & Tuesday & Wed. & Thursday & Friday & Saturday \\
\hline $7-8 \mathrm{am}$ & & Breakfast & Breakfast & Breakfast & Breakfast & Breakfast & \\
\hline 8-9 am & & \multirow{2}{*}{$\begin{array}{l}\text { Project } \\
\text { Mgmt. }\end{array}$} & \multirow{2}{*}{$\begin{array}{c}\text { Map } \\
\text { Reading }\end{array}$} & \multirow{2}{*}{ Design 1} & \multirow{2}{*}{$\begin{array}{l}\text { Bridge } \\
\text { Design }\end{array}$} & \multirow{2}{*}{ Environ } & Breakfast \\
\hline $9-9: 30$ & & & & & & & \multirow{2}{*}{$\begin{array}{l}\text { Personal } \\
\text { Time }\end{array}$} \\
\hline $9: 30-10$ & & \multirow{2}{*}{$\begin{array}{l}\text { Operations } \\
\text { Analysis } 1\end{array}$} & \multirow{2}{*}{$\begin{array}{l}\text { Operations } \\
\text { Analysis } 2\end{array}$} & \multirow{2}{*}{$\begin{array}{l}\text { Landscape } \\
\text { Architect. }\end{array}$} & \multirow{2}{*}{ Design 2} & \multirow{2}{*}{$\begin{array}{c}\text { Computer } \\
\text { Engr } 1\end{array}$} & \\
\hline $10-11 \mathrm{am}$ & & & & & & & \multirow{4}{*}{$\begin{array}{c}\text { Field Trip } \\
10 \text { AM to } \\
3 \mathrm{PM}\end{array}$} \\
\hline $11-12: 30$ & & Math 1 & Surveying & Math 2 & Commun 1 & $\begin{array}{c}\text { Elecrical } \\
\text { Engr } 1\end{array}$ & \\
\hline $\begin{array}{c}12: 30- \\
1: 30\end{array}$ & & Lunch & Lunch & Lunch & Lunch & Lunch & \\
\hline $1: 30-3$ & & $\begin{array}{c}\text { Pre- } \\
\text { Program } \\
\text { Assess }\end{array}$ & $\begin{array}{c}\text { Guest } \\
\text { Speaker }\end{array}$ & \multirow{4}{*}{$\begin{array}{l}\text { Field Trip } \\
\text { Bay Bridge }\end{array}$} & \multirow{3}{*}{$\begin{array}{l}\text { Activities } \\
\text { Exploring } \\
\text { Bridges }\end{array}$} & Commun 2 & \\
\hline 3-4 pm & Regist. & $\begin{array}{l}\text { Commun. } \\
\text { Activity }\end{array}$ & \multirow{2}{*}{$\begin{array}{l}\text { Blind } \\
\text { Obstacle } \\
\text { Course }\end{array}$} & & & $\begin{array}{l}\text { Personal } \\
\text { Time }\end{array}$ & \multirow{3}{*}{$\begin{array}{l}\text { Personal } \\
\text { Time }\end{array}$} \\
\hline $4-5: 30$ & $\begin{array}{l}\text { Welcome } \\
\text { Ceremony }\end{array}$ & \multirow{2}{*}{$\begin{array}{l}\text { Interview } \\
\text { Students/ } \\
\text { Team } \\
\text { Building }\end{array}$} & & & & \multirow{2}{*}{$\begin{array}{l}\text { Group } \\
\text { Activity }\end{array}$} & \\
\hline $5: 30-6$ & $\begin{array}{c}\text { Campus } \\
\text { Tour }\end{array}$ & & $\begin{array}{c}\text { Personal } \\
\text { Time }\end{array}$ & & $\begin{array}{c}\text { Personal } \\
\text { Time }\end{array}$ & & \\
\hline 6-7 pm & Dinner & Dinner & Dinner & Dinner & Dinner & Dinner & Dinner \\
\hline $7-8: 30$ & $\begin{array}{l}\text { Group } \\
\text { Activity }\end{array}$ & Project & Project & Project & Project & Project & \\
\hline 8-9 pm & $\begin{array}{c}\text { Project } \\
\text { Info }\end{array}$ & Time & Time & Time & Time & Time & $\begin{array}{c}\text { Activity / } \\
\text { Movie } \\
\text { Night }\end{array}$ \\
\hline $9-10 \mathrm{pm}$ & $\begin{array}{l}\text { Personal } \\
\text { Time }\end{array}$ & $\begin{array}{c}\text { Personal } \\
\text { Time }\end{array}$ & $\begin{array}{l}\text { Personal } \\
\text { Time }\end{array}$ & $\begin{array}{l}\text { Personal } \\
\text { Time }\end{array}$ & $\begin{array}{l}\text { Personal } \\
\text { Time }\end{array}$ & $\begin{array}{l}\text { Personal } \\
\text { Time }\end{array}$ & \\
\hline $10: 30 \mathrm{pm}$ & Lights Out & Lights Out & Lights Out & Lights Out & Lights Out & Lights Out & In Rooms \\
\hline
\end{tabular}


Appendix B-2

2009 Summer Engineering Institute Schedule: Week 2

\begin{tabular}{|c|c|c|c|c|c|c|}
\hline & July 26 & July 27 & July 28 & July 29 & July 30 & July 31 \\
\hline Time & Sunday & Monday & Tuesday & Wednesday & Thursday & Friday \\
\hline 7:00-8:00 am & & Breakfast & Breakfast & Breakfast & Breakfast & Breakfast \\
\hline 8:00-8:30 am & & \multirow{2}{*}{ Hydraulics } & \multirow{2}{*}{ Design 4} & \multirow{2}{*}{ Elec. Eng. 2} & \multirow{4}{*}{$\begin{array}{l}\text { Project } \\
\text { Time }\end{array}$} & \multirow{4}{*}{$\begin{array}{c}\text { Presentation } \\
\text { s } \\
\text { (HSS-154) }\end{array}$} \\
\hline 8:30-9:30 am & Breakfast & & & & & \\
\hline 9:30-11:00 am & $\begin{array}{l}\text { Personal } \\
\text { Time }\end{array}$ & Design 3 & Elec. Eng. 2 & $\begin{array}{l}\text { Comp. } \\
\text { Eng.3 }\end{array}$ & & \\
\hline $11: 00-12: 30$ & \multirow{4}{*}{$\begin{array}{c}\text { BBQ } \\
\& \\
\text { Fun Games }\end{array}$} & $\begin{array}{c}\text { Comp. Eng. } \\
2\end{array}$ & Geo Tech & Commun. 3 & & \\
\hline $12: 30-1: 30 \mathrm{pm}$ & & Lunch & Lunch & Lunch & Lunch & \multirow{3}{*}{$\begin{array}{l}\text { Closing / } \\
\text { Awards } \\
\text { Banquet }\end{array}$} \\
\hline $1: 30-2: 30 \mathrm{pm}$ & & \multirow{4}{*}{ Field Trip } & \multirow{3}{*}{$\begin{array}{l}\text { Going } \\
\text { Green }\end{array}$} & $\begin{array}{l}\text { Guest } \\
\text { Speaker }\end{array}$ & \multirow{4}{*}{$\begin{array}{c}\text { Mock } \\
\text { Presentation } \\
\text { s }\end{array}$} & \\
\hline $2: 30-3: 00 \mathrm{pm}$ & & & & \multirow{3}{*}{ Robotics } & & \\
\hline $3: 00-3: 30 \mathrm{pm}$ & \multirow{3}{*}{$\begin{array}{l}\text { Project } \\
\text { Time }\end{array}$} & & & & & \multirow{2}{*}{$\begin{array}{l}\text { Checkout } \\
\text { time }\end{array}$} \\
\hline $3: 30-5: 00 \mathrm{pm}$ & & & $\begin{array}{l}\text { Solar } \\
\text { Project }\end{array}$ & & & \\
\hline $5: 00-6: 00 \mathrm{pm}$ & & $\begin{array}{l}\text { Personal } \\
\text { Time }\end{array}$ & $\begin{array}{l}\text { Personal } \\
\text { Time }\end{array}$ & $\begin{array}{l}\text { Personal } \\
\text { Time }\end{array}$ & $\begin{array}{l}\text { Personal } \\
\text { Time }\end{array}$ & \\
\hline $6: 00-7: 00 \mathrm{pm}$ & Dinner & Dinner & Dinner & Dinner & Dinner & \\
\hline 7:00-8:00 pm & \multirow{2}{*}{$\begin{array}{c}\text { Communica } \\
\text { tion } \\
\text { Activity }\end{array}$} & \multirow{3}{*}{$\begin{array}{l}\text { Project } \\
\text { Time }\end{array}$} & \multirow{3}{*}{$\begin{array}{l}\text { Project } \\
\text { Time }\end{array}$} & \multirow{3}{*}{$\begin{array}{l}\text { Project } \\
\text { Time }\end{array}$} & $\begin{array}{l}\text { Personal } \\
\text { Time }\end{array}$ & \\
\hline 8:00-8:30 pm & & & & & \multirow{3}{*}{ Party } & \\
\hline 9:00-10:00 pm & \multirow{2}{*}{$\begin{array}{l}\text { Personal } \\
\text { Time }\end{array}$} & & & & & \\
\hline 9:30-10:00 pm & & $\begin{array}{l}\text { Personal } \\
\text { Time }\end{array}$ & $\begin{array}{l}\text { Personal } \\
\text { Time }\end{array}$ & $\begin{array}{l}\text { Personal } \\
\text { Time }\end{array}$ & & \\
\hline $10: 30 \mathrm{pm}$ & Lights Out & Lights Out & Lights Out & Lights Out & Lights Out & \\
\hline
\end{tabular}

